\title{
FLOATING IN MY TIN CAN
}

\author{
Lullaby for life.
}

\section{BY GERRI LEEN}

$\mathrm{I}$ always thought that if I died in space, I would take my last breaths surrounded by stars and the detritus of the fleet of the five federations. But I've wandered off course, my new nav system is failing, and now I'm running blind with a life-support system that is dying.

I have enemies. They know how to sabotage a ship. I check: I always check. But the new nav system's readings must have masked whatever they did to the life support. It waited to fail until I was too far from anywhere to call for help.

No beacons ping on my comm system, not even from the farthest planets out.

Genina, obsessive and damaged, was from one of the outer planets. Her voice was lovely when she sang. I wish I had a recording of her, especially when she sang the lullaby her mother had sung to her.

Her voice made me feel safe, the way I hadn't since I was a child. Before men from the first federation came and took my parents away. Before I was handed over to protective services and sent to the children's home, where the refuse of the five federations go.

Where they taught freedom as a code word for conforming. Where we had what was expected drilled into us. But at night, when the lights were out, Genina and I fought back in the room that we shared. We discovered things that made us unique and incandescent, like the stars I longed to fly among. Genina never wanted space; she wanted to be free to sing her songs.

My dreams were of steering a ship anywhere that would make us free.

In the children's home, Genina would sing quietly as we shared her bed, skin to skin, the covers pulled over us, until one night the matrons found out and separated us.

After that, I'd see Genina in the halls, and when she spoke, her voice was different, cracked and dusty, as if she'd been denied water.

It was hard to get her alone, but I finally did. She wouldn't touch me and she didn't want to sing. But I begged and eventually she sang the lullaby. I wept - what came out of her mouth was no longer song.

She didn't cry; she just touched my cheek and went back to her room. They found her floating in the river a week later. I think it was my fault - if I hadn't asked her to sing,

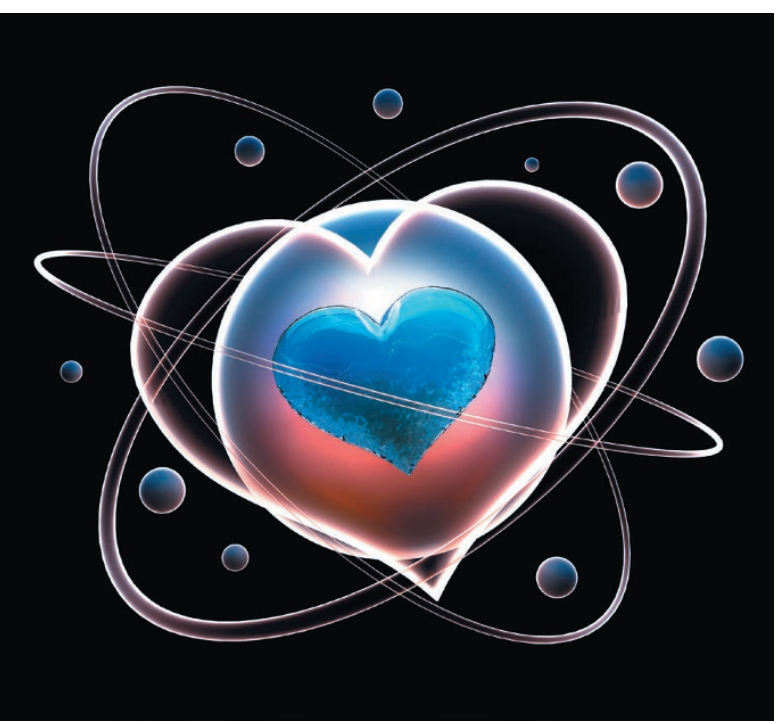

time at all as far as the sleepers know.

Would they want to spend the time left to them singing? Or just dreaming of song?

I finger the console. An almost musical combination of keystrokes will wake them up.

Or I can let them sleep - the cold changing their slumber to a more lasting rest as the power runs out, while the inside of the ship begins to resemble their cryo chamber and I freeze to death.

But ... I long to hear their voices again. Maybe they know Genina's lullaby. I didn't ask when they boarded. They're not from her planet, but songs travel.

I push down on the first key. With a ping, 'Initiate awakening?' blinks on the screen.

she might not have realized what she'd lost.

I leave the ship on autopilot and check the cryo units, normally well hidden, but there's no reason to keep them camouflaged now that I'm floating blind. My cargo is asleep, deep in frozen dreams. They paid me to get them out of the five federations. They are singers, you see.

I rescue singers from those who would destroy the songs.

Or I did. Now ... now I drift with them safely in cryo and think about ways to make this right.

I suppose I should console myself with knowing I did get them free of the five federations. I just didn't get them all the way. Would that be a consolation? That they're free for now?

They sang for me, these two lovers who wanted to share a cryo pod until I explained how that wouldn't work. The way they looked at each other reminded me of how Genina used to smile at me. Their voices trilled in half-step harmonies that made me shiver. So discordant and yet ... beautiful.

These two should have been in their new home by now, being lauded by audiences, after they'd sung one last song for me - I asked all my runners for that. Credits, too, of course - a song wouldn't buy fuel - but that last song always sounded the sweetest. Hope coloured it with something beautiful. $\rightarrow$ NATURE.COM

Follow Futures: @NatureFutures

f go.nature.com/mtoodm
But now it's hopeless and we float and wait for our air to run out. It will be a while, from my perspective. No
I have done this before, five times. Each time I have chosen 'No'.

I hit 'No' again.

I try to remember how Genina's song went. My voice cracks and bends around notes that may be right but certainly sound nothing like those she made so magical.

"I'm sorry," I say to Genina, as I say every night.

As I say now to these two lovers, whom I have failed.

As I say to myself, as I turn back to the command console, take my seat, and try to figure a way out of this even though I know there isn't one.

I think of the cascading trill of my two frozen lovebirds. Wouldn't they rather die together, knowing their time was ending? Singing?

Or is that just what I want?

Every time I go back to the cryo chambers, I ask myself this, and I let them sleep.

Genina's lullaby would sound like a dirge in two-step harmony. It would be ... fitting.

No - I will let them sleep.

Won't I? -

Gerri Leen lives in Northern Virginia and originally hails from Seattle. She has stories and poems published by Daily Science Fiction, Escape Pod, Grimdark, Enchanted Conversation and others. Her first solo editing gig, the A Quiet Shelter There anthology published by Hadley Rille Books, was released in autumn 2015 and benefits homeless animals. See more at http://www.gerrileen.com. 